\title{
Vitamin C content in Habanero pepper accessions (Capsicum chinense)
}

\author{
Ana Flávia P Teodoro ${ }^{1}$; Rosa de BN Alves ${ }^{1}$; Leandro B Ribeiro ${ }^{1}$; Karina Reis ${ }^{2}$; Francisco José B \\ Reifschneider $^{2}$; Maria Esther de N Fonseca ${ }^{2}$ Joseane P da Silva $^{1}$; Tânia da S Agostini-Costa ${ }^{1}$ \\ 'Embrapa Recursos Genéticos e Biotecnologia, C. Postal 02372, 70770-900 Brasília-DF; rbelem@cenargen.embrapa.br; tania@cenargen. \\ embrapa.br; ${ }^{2}$ Embrapa Hortaliças, C. Postal 218, 70351-970 Brasília-DF; mesther@enph.embrapa.br; fjbr@enph.embrapa.br
}

\begin{abstract}
Fruits of Capsicum species (peppers) accumulate high amounts of ascorbic acid or vitamin C. C. chinense occurs in the Midwest and Northeast regions and the Amazon Basin (where its greatest genetic diversity is found). The objective of the present work was to quantify the vitamin $\mathrm{C}$ content in peppers of 22 accessions of $C$. chinense 'Habanero' from the Breeding Program of Embrapa Vegetable Crops. Vitamin $\mathrm{C}$ was extracted from mature fruits with TCEP-HCl (tris 2-carboxyethyl-phosphine hydrocloride) and its content determined by high performance liquid chromatography (HPLC). Vitamin C content ranged from 54.1 to $129.8 \mathrm{mg} / 100 \mathrm{~g}$. Accessions were divided into four heterogeneous groups of diversity. Vitamin C content of the first group varied between 116.2 and $129.8 \mathrm{mg} / 100 \mathrm{~g}$; the second group ranged from 94.0 to $104.6 \mathrm{mg} / 100 \mathrm{~g}$; the third group ranged from 76.7 to $87.5 \mathrm{mg} / 100 \mathrm{~g}$; and the fourth group ranged from 54.1 to $66.6 \mathrm{mg} / 100 \mathrm{~g}$. These results highlight the diversity of $C$. chinense collection in terms of vitamin $\mathrm{C}$ content.
\end{abstract}

Keywords: Pepper, ascorbic acid, genetic resource, high performance liquid chromatography (HPLC).

\section{RESUMO}

Teor de vitamina $\mathrm{C}$ em acessos de pimenta (Capsicum chinense) do grupo varietal Habanero

Os frutos de Capsicum possuem elevados teores de ácido ascórbico ou vitamina C. A pimenta (C. chinense) ocorre nas regiões Centro-Oeste e Nordeste e na Bacia Amazônica (onde está localizada a sua maior diversidade genética). O objetivo deste trabalho foi quantificar o teor de vitamina $\mathrm{C}$ em 22 acessos de $C$. chinense do grupo varietal 'Habanero', procedentes do programa de melhoramento genético da Embrapa Hortaliças. A vitamina $\mathrm{C}$ foi extraída de frutos maduros com TCEP-HCl (tris 2-carboxyethyl-phosphine hydrocloride) e os teores foram determinados por cromatografia líquida de alta eficiência (CLAE). Os teores de vitamina C variaram entre 54,1-129,8 $\mathrm{mg} / 100 \mathrm{~g}$. Foram formados, com base no teor de vitamina C, quatro grupos heterogêneos de diversidade. Os teores do primeiro grupo variaram entre $116,2-129,8 \mathrm{mg} / 100 \mathrm{~g}$; o segundo variou entre $94,0-$ $104,6 \mathrm{mg} / 100 \mathrm{~g}$; o terceiro entre $76,7-87,5 \mathrm{mg} / 100 \mathrm{~g}$; e o quarto entre $54,1-66,6 \mathrm{mg} / 100 \mathrm{~g}$. Esses resultados evidenciam a diversidade dessa coleção de $C$. chinense para os teores de vitamina C.

Palavras-chave: Ácido ascórbico, recurso genético, cromatografia líquida de alta eficiência (CLAE).

(Recebido para publicação em 22 de novembro de 2011; aceito em 9 de novembro de 2012) (Received on November 22, 2011; accepted on November 9, 2012)

$\mathrm{P}$ eppers of the genus Capsicum were already used in the diet of preColombian American peoples in many recipes, generally as part of sauces or as spice (Reifschneider \& Ribeiro, 2008). Capsicum chinense occurs in the Brazilian Midwest and Northeast regions and in the Amazon Basin (where its greatest genetic diversity is found).

Several bioactive substances are present in fruits of hot and sweet pepper plants, especially the alkaloid capsaicin (that gives pungency), vitamin E, pro-vitamin A carotenoids, flavonoids and other secondary metabolites with antioxidant properties (Perucka \& Materska, 2003; Matsufuji et al., 2007; Oboh \& Rocha, 2007; Sun et al., 2007; Topuz \& Ozdemir, 2007; Menichini et al., 2009). Fresh peppers are also excellent sources of ascorbic acid (vitamin C), which participates in several antioxidant processes in plants besides acting in the prevention of human chronic diseases, including certain types of cancer, coronary disorder, arteriosclerosis and cataracts (Howard et al., 2000). The hot peppers (including several representatives of C. chinense) have great importance in the American continent and in tropical regions of the world. These products are essential in Mexican, African and Asian cuisines. In Brazil, C. frutescens (malagueta pepper) and $C$. chinense (pimenta de cheiro), are irreplaceable ingredients in several regional dishes. The acarajé and vatapá in Bahia state, the chicken with okra in Minas Gerais state, the duck with tucupi in Pará state and the fish stew and chowder in several coastal cities of the Northeast and Southeast are some examples (Ribeiro \& Henz, 2008).

Other lesser known varieties, like "Habanero", have begun to gain a greater importance in Brazil. The varietal group of hot peppers like "Habanero" presents, nowadays, a growing demand in North America and European Economic Community. The high value of this product in the international market is a result of an offer historically lower to the demand and, for this reason, has aroused the interest of national private groups in the development of processed products in this segment. 
The Brazilian germplasm collection of peppers like "Habanero" is very diverse (Carvalho et al., 1999). From the perspective of plant breeding, the characterization of the accessions with higher vitamin $\mathrm{C}$ content is interesting. Because of the red pigmentation of several samples of pepper, vitamin $\mathrm{C}$ content determined by classical method of dichlorophenolindophenol (DCFI) may suffer interference at the turning point. In this context, the aim of this work was to evaluate the methodology by high performance liquid chromatography (HPLC) (Fontanaz et al., 2006) and quantify vitamin $\mathrm{C}$ content in 22 accessions of Habanero peppers ( $C$. chinense) from the Breeding Program of Embrapa Vegetable Crops.

\section{MATERIAL AND METHODS}

Twenty two accessions of $C$. chinense "Habanero" from the Breeding Program of Embrapa Vegetable Crops were evaluated (Table 1). Planting was done in the field, in April 2009, at Embrapa Vegetable Crops, Brasília, Federal District. The fertilization was carried out according to the recommendations for the pepper crop and the plot spacing in the field was $0.4 \mathrm{~m}$ between plants and $0.8 \mathrm{~m}$ between rows. Five plants were grown per accession. In September, about 30 to 40 mature fruits were harvested per accession. In the Chemistry of Natural Products Laboratory at Embrapa Genetic Resources and Biotechnology, the fruits were selected (about 20 fruits per accession), washed, dried with paper towels, wrapped in kraft paper bags and plastic and stored at $4^{\circ} \mathrm{C}$ until the time of extraction.

Each sample (about 20 fruits per accession) was homogenized with skin and seed in hammer mill IKA ${ }^{\circledR}$. About $10 \mathrm{~g}$ of pepper pulp (three replications per sample) were weighed directly in a 100-mL volumetric flask. The vitamin C was extracted and analyzed using high performance liquid chromatography (HPLC), as described by Fontanaz et al. (2006). Briefly, the extraction was done with $40 \mathrm{~mL}$ of TCEPHCI (tris 2-carboxyethyl-phosphine hydrocloride), adding about $30 \mathrm{mg}$ of takadiastase with incubation at $30^{\circ} \mathrm{C}$ for
$30 \mathrm{~min}$; the volume was completed up to $100 \mathrm{~mL}$ with $1 \%$ trichloroacetic acid (TCA). The extract was filtered through paper and filter Millex LCR $13 \mathrm{~mm}$ with a modified PTFE membrane and it was analyzed using HPLC.

The equipment used was a chromatograph (HPLC) Varian ${ }^{\circledR}$ equipped with a quaternary pump, automatic injector and photodiode array detector controlled by software Galaxie $^{\circledR}$, using LiChospher column RP-18, $5 \mu \mathrm{m}, 4.6 \times 250 \mathrm{~mm}$; isocratic elution $1 \mathrm{~mL} / \mathrm{min}$; detection at 265 $\mathrm{nm}$; injection volume of $20 \mu \mathrm{L}$. Mobile phase: $1.6 \mathrm{~g}$ of decylamine: $80 \mathrm{~mL}$ of acetonitrile: $100 \mathrm{~mL}$ of $0.25 \mathrm{M}$ sodium acetate pH 5.4: water up to $1000 \mathrm{~mL} ; 50$ $\mathrm{mg}$ of TCEP-HCl in the final solution. The ascorbic acid identification was made by co-chromatography with standard and through comparison of the spectral profile provided by a diode array detector.

The quantification of the vitamin $\mathrm{C}$ content in the different accessions of $C$. chinense was carried out using external calibration curve, which was linear using six concentrations of ascorbic acid $\left(\mathrm{Sigma}^{\circledR}\right)$ ranging from 0.3 to 1.5 $\mathrm{mg} \mathrm{mL}^{-1}(\mathrm{r}=0.999)$.

For the statistical analysis, Euclidian distant matrices between the accessions were determined, used as a measure of dissimilarity for the cluster analysis of genotypes by the average distance method (UPGMA, Unweighted PairGroup Method using an Arithmetic Average). The analysis of variance (ANOVA) at 5\% significance was used to test the hypothesis of the difference between the mean vectors of each group.

Table 1. Vitamin C content in 22 genotypes of Capsicum chinense (Habanero) [teor de vitamina $\mathrm{C}$ em 22 genótipos de Capsicum chinense (Habanero)]. Brasília, Embrapa Recursos Genéticos e Biotecnologia, 2009.

\begin{tabular}{|c|c|c|c|c|}
\hline $\begin{array}{l}\text { Access } \\
\text { CNPH }\end{array}$ & Color & $\begin{array}{l}\text { Vitamin } C^{*} \\
(\mathrm{mg} / 100 \mathrm{~g})\end{array}$ & DP & CV $(\%)$ \\
\hline 15035 & light red & 129.8 & 5.5 & 4.2 \\
\hline 15027 & light red & 128.1 & 1.5 & 1.3 \\
\hline 15041 & light red & 124.9 & 1.9 & 1.6 \\
\hline 15045 & red & 124.0 & 0.6 & 0.5 \\
\hline 15030 & light orange & 123.7 & 4.3 & 3.5 \\
\hline 15033 & dark red & 123.4 & 1.8 & 1.6 \\
\hline 15044 & orange & 121.7 & 5.6 & 4.8 \\
\hline 15032 & light orange & 116.2 & 3.5 & 3.0 \\
\hline 15042 & light orange & 104.6 & 2.9 & 2.8 \\
\hline 15039 & orange & 103.8 & 1.7 & 1.6 \\
\hline 15028 & orange & 98.2 & 3.6 & 3.7 \\
\hline 15038 & orange & 98.1 & 0.8 & 0.8 \\
\hline 15029 & light red & 94.0 & 1.5 & 1.6 \\
\hline 15025 & dark red & 90.2 & 6.0 & 6.4 \\
\hline 15036 & light orange & 87.5 & 2.8 & 3.2 \\
\hline 15043 & red & 85.0 & 0.3 & 0.4 \\
\hline 15040 & orange & 82.2 & 1.8 & 2.2 \\
\hline 15037 & red & 76.7 & 2.0 & 2.6 \\
\hline 15024 & dark red & 66.6 & 4.2 & 6.3 \\
\hline 15026 & dark red & 64.5 & 1.8 & 2.8 \\
\hline 15034 & light orange & 60.4 & 0.6 & 0.9 \\
\hline 15031 & red & 54.1 & 1.1 & 1.9 \\
\hline
\end{tabular}

*Each value represents the mean of triplicate determination; $\mathrm{DP}=$ standard deviation; $\mathrm{CV}$ $(\%)=$ coefficient of variation $(*$ cada valor é média de determinações em triplicata; $\mathrm{DP}=$ desvio padrão; CV (\%)= coeficiente de variação); light red (vermelho claro); red (vermelho); light orange (laranja pálido); dark red (vermelho escuro); orange (laranja). 


\section{RESULTS AND DISCUSSION}

The HPLC analytical methodology used in this work (Fontanaz et al., 2006) showed extract stability and enabled the determination of vitamin $\mathrm{C}$ interferencefree from colorful compounds or from other antioxidants (Figure 1). In Figure 1 only the chromatogram of accession CNPH '15027' was presented because the chromatograms of all the evaluated accessions showed the same chromatographic profile. The extraction solution used in HPLC method for analysis (with TCEP/TCA) showed the advantage of higher stability, when stored under refrigeration and protected from the light, if compared to the extraction using only acid solution (TCA).

The vitamin $\mathrm{C}$ contents ranged from 54.1 to $129.8 \mathrm{mg} / 100 \mathrm{~g}$ (Table 1). Based on vitamin $C$ content, four heterogeneous groups of diversity were formed (Figure 2). The contents of the first group ranged from 116.2 to 129.8 $\mathrm{mg} / 100 \mathrm{~g}$, with average of $123.5 \pm 8.9$ $\mathrm{mg} / 100 \mathrm{~g}$; the second group ranged from 94.0 to $104.6 \mathrm{mg} / 100 \mathrm{~g}$, with average of $98.1 \pm 6.2 \mathrm{mg} / 100 \mathrm{~g}$; the third group ranged from 76.6 to $90.0 \mathrm{mg} / 100 \mathrm{~g}$, with average of $82.0 \pm 4.8 \mathrm{mg} / 100 \mathrm{~g}$; the fourth group ranged from 54.1 to 66.6 $\mathrm{mg} / 100 \mathrm{~g}$, with average of $61.4 \pm 5.4$ $\mathrm{mg} / 100 \mathrm{~g}$.

According to Lutz \& Freitas (2008), the vitamin $\mathrm{C}$ content in Brazilian peppers, like "dedo-de-moça" $(C$. baccatum), biquinho, cumari-do-Pará, murupi (C. chinense), de-cheiro, debode, malagueta (C. frutescens) and jalapeño ( $C$. annuum) ranges from $52.0 \mathrm{mg} / 100 \mathrm{~g}$ (jalapeño and dedo-demoça) to $134.0 \mathrm{mg} / 100 \mathrm{~g}$ (murupi); the ascorbic acid contents determined in 17 accessions of Capsicum Breeding Program of Embrapa Vegetable Crops, Brasília, through the titrimetric method of Tillmans, ranged from 22.0 to 148.0 $\mathrm{mg} / 100 \mathrm{~g}$. The evaluation of a green and red cultivar of $C$. chinense var. Habanero grown in Santa Maria, Rio Grande do Sul state, showed 10.4 and $15.3 \mathrm{mg} / 100$ $\mathrm{g}$ of vitamin C, respectively (Oboh et al., 2007). For peppers grown in the United States, two Habanero cultivars (cv. Francisca and cv. Red Savina) showed vitamin $C$ contents of 122.0 and 115.0 $\mathrm{mg} / 100 \mathrm{~g}$, respectively (Howard et al., 2000). However, an extensive study of North American Germplasm, consisting of 216 different $C$. chinense accessions from North, South and Central America (Jarret et al., 2009) showed a greater range of variation for ascorbic acid contents ( 30.0 to $1466.0 \mathrm{mg} / 100 \mathrm{~g}$, with average of $391 \mathrm{mg} / 100 \mathrm{~g}$ ) and pointed that Habanero varietal group can be further improved with respect to that trait.

The ascorbic acid and vitamin $\mathrm{C}$, besides nutritional potential, contain antioxidant properties and it is present in high concentrations in several types of peppers. Maturation and storage conditions can also affect the stability and accumulation of vitamin $\mathrm{C}$ in fruits of Capsicum, besides genetic diversity (Howard et al., 2000; Jimenez et al., 2003). However, all the peppers used in this experiment were grown under the same controlled field conditions, allowing, this way, a comparative analysis.

The results showed variation in vitamin $\mathrm{C}$ contents in the accessions of this collection of $C$. chinense Habanero varietal group and also indicated potential to improve this variety for this vitamin. Some accessions showed vitamin $\mathrm{C}$ above the current daily recommendation for human diet, which is between 75 and $90 \mathrm{mg}$ (Chen et al., 2003). Thus, the in natura consumption or the consumption in spicy sauces with higher antioxidants contents

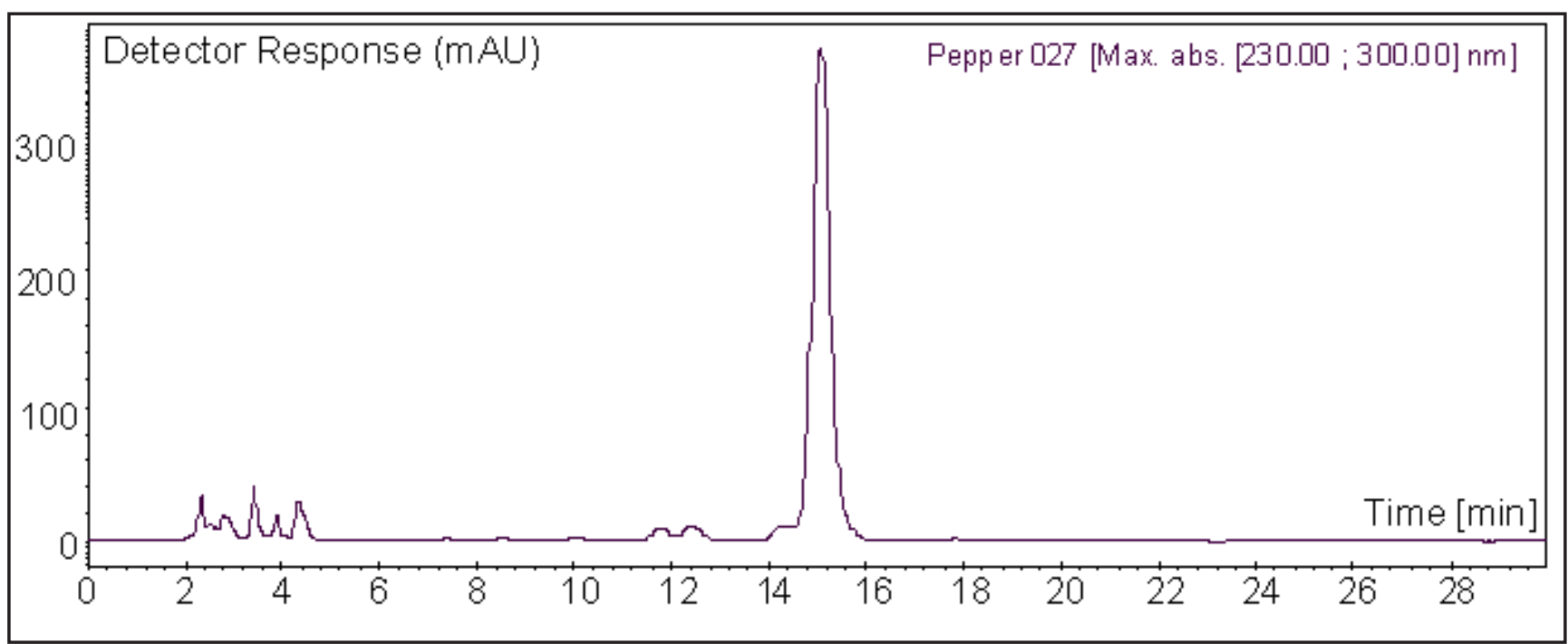

Figure 1. Ascorbic acid determination in C. chinense (access 'CNPH 15027'), using LiChospher column RP-18.5 $\mu \mathrm{m}$, $4.6 x 250$ mm; mobile phase: $1.6 \mathrm{~g}$ of decilamine: $80 \mathrm{~mL}$ of acetronitrile: $100 \mathrm{~mL}$ of $0.25 \mathrm{M}$ sodium acetate $\mathrm{pH} 5.4$ : water qsp $1000 \mathrm{~mL} ; 50 \mathrm{mg}$ TCEP-HCl in the final solution; flow: $1 \mathrm{~mL} / \mathrm{min}$; detection: $265 \mathrm{~nm}$ [cromatograma (CLAE) de determinação de vitamina C (ácido ascórbico) total em $C$. chinense (acesso 'CNPH 15027'), usando coluna LiChospher RP-18,5 $\mu \mathrm{m}, 4,6 \times 250 \mathrm{~mm}$; fase móvel: 1,6 g de decilamina: $80 \mathrm{~mL}$ de acetronitrila: $100 \mathrm{~mL}$ de acetato de sódio 0,25 M pH 5,4: água qsp $1000 \mathrm{~mL} ; 50 \mathrm{mg}$ de TCEP-HCl na solução final; fluxo: $1 \mathrm{~mL} / \mathrm{min}$; detecção: $265 \mathrm{~nm}$ (HPLC chromatogram for total vitamin C)]. Brasília, Embrapa Recursos Genéticos e Biotecnologia, 2009. 


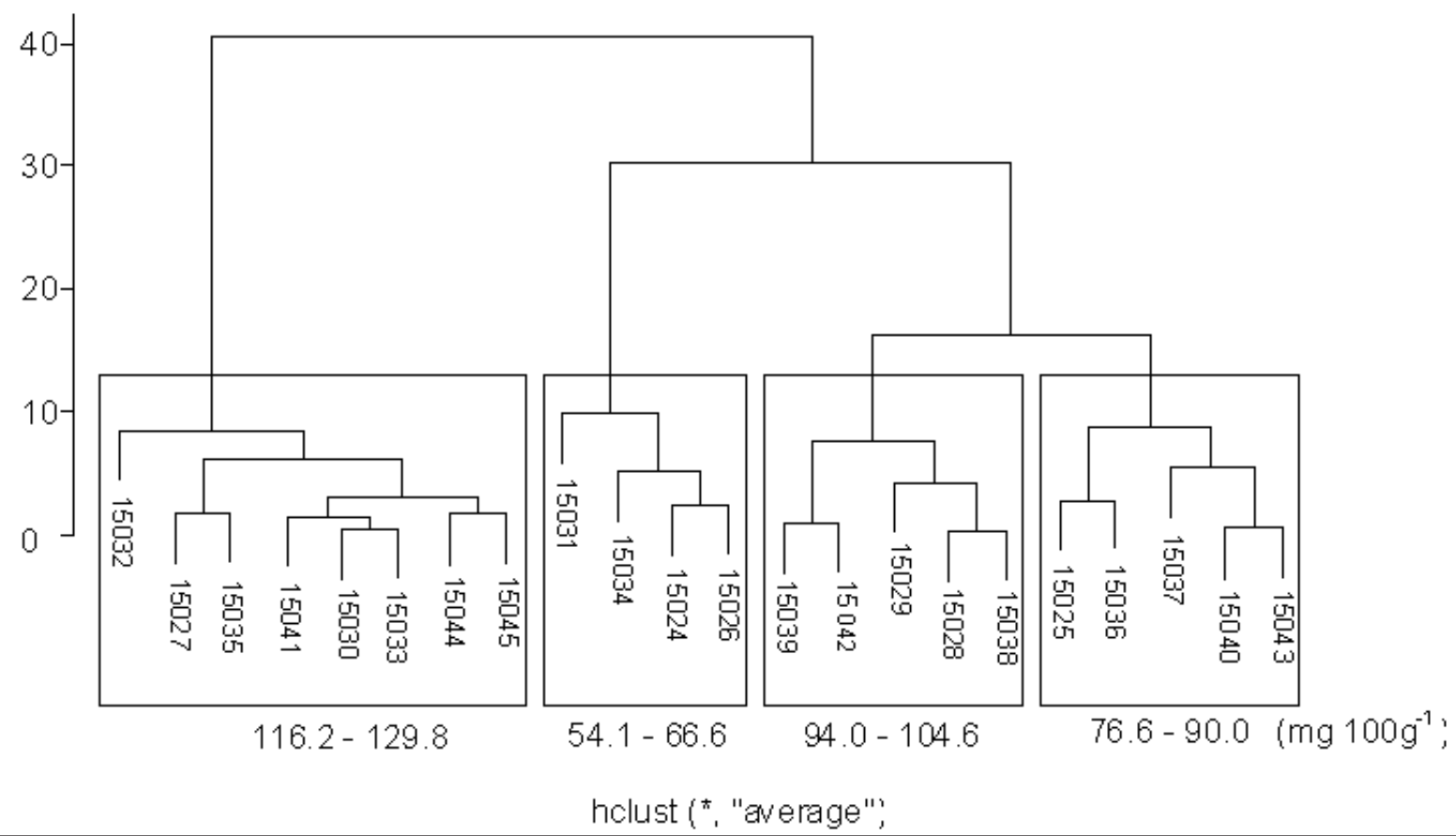

Figure 2. Cluster analysis of 22 accessions of $C$. chinense Habanero originating from the breeding program of Embrapa Vegetables, conducted under controlled conditions in field, based on the matrix of standardized mean Euclidean distances, according to the levels of vitamin C (análise de agrupamento de 22 acessos de C. chinense do grupo Habanero, procedentes do programa de melhoramento genético da Embrapa Hortaliças, conduzidos em condições controladas de campo, com base na matriz de distâncias euclidianas médias padronizadas, calculadas com base nos teores de vitamina C). Brasília, Embrapa Recursos Genéticos e Biotecnologia, 2009.

may contribute to these daily values to be achieved in a larger number of consumers.

\section{REFERENCES}

CARVALHO SIC; REIFSCHNEIDER FJB; RIBEIRO CSC; BIANCHETTI LB; BUSTAMANTE PG. 1999. Multiplicação, caracterização, conservação e documentação da coleção de germoplasma de Capsicum da Embrapa Hortaliças. Horticultura Brasileira 17: 280.

CHEN Z; YOUNG TE; LING J; CHANG SC; GALLIE DR. 2003. Increasing vitamin C content of plants through enhanced ascorbate recycling. Proceedings of the National Academy of Sciences 100: 3525-3530.

FONTANAZ P; KILINC T; HEUDIO O. 2006. HPLC-UV determination of total vitamin $C$ in a wide range of fortified food products. Food Chemistry 94: 626-631.

HOWARD LR; TALCOTT ST; BRENES $\mathrm{CH}$; VILLALON B. 2000. Changes in phytochemical and antioxidant activity of selected pepper cultivar as influenced by maturity. Journal of Agriculture and Food Chemistry 48: 1713-1720.

JARRET RL; BERKE T; BALDWIN EA;
ANTONIOUS GF. 2009. Variability of free sugars and organic acids in Capsicum chinense. Chemistry and Biodiversity 6: 138-145.

JIMENEZ A; ROMOJARO F; GOMEZ JM; LLANOS MR; SEVILLAF. 2003. Antioxidant systems and their relationship with the response of pepper fruits to storage at $20^{\circ} \mathrm{C}$. Journal of Agriculture and Food Chemistry 51: 6293-6299.

LUTZ DL; FREITAS SC. 2008. Valor nutricional. In: RIBEIRO CS; LOPES CA; CARVALHO SIC; HENZ GP; REIFSCHNEIDER FJB (eds). Pimentas - Capsicum. Brasília: Embrapa Hortaliças. p. 31-38.

MATSUFUJI H; ISHIKAWA K; NUNOMURAO; CHINO M; TAKEDA M. 2007. Antioxidant content of different coloured sweet peppers, white, green, yellow, orange and red (Capsicum annuum L.). International Journal of Food Science and Technology 42: 1482-1488.

MENICHINI F; TUNDIS R, BONESI M; LOIZZO MR; CONFORTI F; STATTI G; CINDIO B; HOUGHTON PJ; MENICHINI F. 2009. The influence of fruit ripening on the phytochemical content and biological activity of Capsicum chinense Jacq. cv Habanero. Food Chemistry 114: 553-560.

OBOH G; PUNTEL RL; ROCHA JBT. 2007. Hot pepper (Capsicum annuum, Tepin and Capsicum chinense, Habanero) prevents $\mathrm{Fe} 2+-$ induced lipid peroxidation in brain - in vitro. Food Chemistry 102: 178-185.

OBOH G; ROCHA JBT. 2007. Distribution and antioxidant activity of polyphenols in ripe and unripe tree pepper (Capsicum pubescens). Journal of Food Biochemistry 31: 456-473.

PERUCKAI; MATERSKAMG. 2003. Antioxidant activity and content of capsaicinoids isolated from paprika fruits. Polish Journal of Food and Nutrition Sciences 53: 15-18.

REIFSCHNEIDER FJB; RIBEIRO CSC. 2008. Cultivo. In: RIBEIRO CSC; LOPES CA; CARVALHO SIC; HENZ GP; REIFSCHNEIDER FJB (eds). Pimentas Capsicum. Brasília: Embrapa Hortaliças. p. 11-14.

RIBEIRO CSC; HENZ GP. 2008. Processamento. In: RIBEIRO CSC; LOPES CA; CARVALHO SIC; HENZ GP; REIFSCHNEIDER FJB (eds). Pimentas - Capsicum. Brasília: Embrapa Hortaliças. p. 157-187.

SUN T; XU Z; WU CT; JANES M; PRINYAWIWATKUL W; NO HK. 2007. Antioxidant activities of different colored sweet bell peppers (Capsicum annum L.) Journal of Food Science 72: S98-S102.

TOPUZ A; OZDEMIR F. 2007. Assessment of carotenoids, capsaicinoids and ascorbic acid composition of some selected pepper cultivars (Capsicum annuum L.) grown in Turkey. Journal of Food Composition and Analysis 20: 596-602. 